\title{
Microcoil Embolization for Acute Lower Gastrointestinal Bleeding
}

\author{
B. Janne d'Othée · Padmaja Surapaneni · \\ Dmitry Rabkin · Imad Nasser · Melvin Clouse
}

Published online: 18 October 2007

(C) Springer Science+Business Media, LLC 2007

\section{Erratum to: Cardiovasc Intervent Radiol}

\section{DOI 10.1007/s00270-004-0301-4}

Re: Cardiovasc Intervent Radiol (2006) 29:49-58-In the online version of this article, the first author's name was cited incorrectly. It appears correctly below:

B. Janne d'Othée

The online version of the original article can be found under doi: 10.1007/s00270-004-0301-4

B. Janne d'Othée $(\varangle)$ · P. Surapaneni · D. Rabkin · M. Clouse Department of Radiology, Beth Israel Deaconess Medical Center - Harvard Medical School, 330 Brookline Avenue-W/CC

335, Boston, MA 02215-5400, USA

e-mail: bjanne@caregroup.harvard.edu

I. Nasser

Department of Pathology, Beth Israel Deaconess Medical

Center - Harvard Medical School, 330 Brookline Avenue-W/CC

335, Boston, MA 02215-5400, USA 